\title{
Morphological Components and Blood Serum Proteins in Hybrids of the Skunk and Ferret During the Postnatal Period
}

\author{
Henryk BIEGUSZEWSKI \& Roman SZYMECZKO
}

\begin{abstract}
Bieguszewski H. \& Szymeczko R., 1978: Morphological components and blood serum proteins in hybrids of the skunk and ferret during the postnatal period. Acta theriol., 23, 15: 269-276 [With 2 Tables \& Plate XIII].

Examination was made of morphological indexes of blood serum prateins in hybrids of the skunk and ferret of different age. During the first few days of postnatal life the level of red blood corpuscles, haematocrit and haemoglobin in the blood of these animals was low. A change in the electrophoretic picture of their blood serum proteins was found to take place with growth.

[Agric. Techn. Acad., Zootechn. Inst., 85-084 Bydgoszcz, Hanki Sawickiej 28].
\end{abstract}

\section{INTRODUCTION}

There are comparatively few papers to be found in scientific literature on the blood physiology of fur-bearing animals. The studies so far made by the authors (Bieguszewski, 1969; Bieguszewski \& No$\mathrm{wicka}, 1968)$ on the fox shows that the age of these animals exerts a distinct influence on total blood volume, level of morpholugical components and blood serum proteins. A relation was also found between the age of Polar foxes and albumin rotation rate (B i e g u s zew ski, 1971). In 3-month old fox cubs the rate of albumin metabolism was far higher than in adult animals. Age differences were also found in the contents of amino-nitrogen in the blood-plasma of Polar foxes (S tefańczyk \& Bi eguszewski, 1970). Lisicyn (1960), who carried out studies on silver foxes, showed that there were variations in the blood picture of animals from 1 to 10 years old. Gill \& W a lkowiak (1972) examined the electrophoretic fractions of the blood serum in mink during the period from birth up to the 10th day of life. These authors found that at the time of birth all typical protein fractions occur in the blood of the mink. The greatest changes in blood serum proteins took place during the first three days of the mink's life. According to these authors such great changes in the values of different fractions were due to ingestion of large amounts of colostrum by the newborn animals. 
was determined using a spectrophotocolorimeter, with $590 \mathrm{~nm}$ wave length. Thecontrol sample consisted of the eluate from unstained strips of filter paper. The percentage of the different fractions was calculated from the extinctions obtained, taking the sum total of extinctions for the whole filter paper strip as $100 \%$.

The statistical significance of differences between average values for the various morphological components and blood serum proteins was calculated for groups of day old, 2.5 and 4.5 months old hybrids in relation to the group of adult animals (7.5 months old) on a level of significance of 0.05 and 0.01 . Use was made of the equations given by Ruszczy c (1970) for statistical calculations.

\section{RESULTS AND DISCUSSION}

Average values for hematological indexes are given in Table 1 . In the light of the results we obtained it must be concluded that the low level of such indexes as the number of erythrocytes, hematocrite, $\mathrm{Hb}$ content in the blood of skunk-ferret hybrids 1,7 and 30 days old was due to postnatal anaemia. Physiological anaemia has so far been found in newborn animals of many species. This is due to the change from foetal to normal hemoglobin, deficiency of factors taking part in erythropoiesis and the intensive growth of newborn animals. During the first period of postnatal life the rapid growth of the skeleton, skeletal muscles and internal organs lead to temporary insufficiency in haemopoiesis. The aneamia occurring in skunk-ferret hybrids may have been intensified by the lack of a sufficient amount of iron essential to $\mathrm{Hb}$ synthesis.

It is known that the milk of mother animals of many species does not contain a sufficient amount of this element, and in addition the low level of beta globulin in young could have failed to ensure iron transport, in the form of transferin, to the required degree.

The increase in number of erythrocytes, hematocrit and $\mathrm{Hb}$ content in the blood of hybrids 2.5 months old may have been caused by the formation of a fully effective haemopoietic system and better supply to the organism of nutrient components, mineral salts and vitamins after the cubs had changed to solid food.

The mean erythrocyte volume and average $\mathrm{Hb}$ contents in an erythrocyte were highest in hybrids immediately after birth, and lowest in adult individuals. This is evidence of the important changes taking place in the size of erythrocytes and their supply of blood pigment during postembryonic life in these animals.

The number of leucocytes does not exhibit such characteristic changes during the growth of hybrids of the skunk and ferret as does the index of the erythrocyte system. The causes of such considerable fluctuations: in the number of leucocytes in animals of different age are unknown.

The studies made show that $4-6$ protein fractions occur in the blood 
Table 1

Blood of skunk $\times$ ferret hybrids of different age.

\begin{tabular}{|c|c|c|c|c|c|c|}
\hline \multirow[t]{2}{*}{ Hematological indexes } & \multicolumn{6}{|c|}{ Age of animals } \\
\hline & one day & 7 days & 30 days & 2.5 months & 4.5 months & 7.5 months \\
\hline $\begin{array}{l}\text { Number of erythrocytes } \\
\text { per } 1 \mathrm{~mm}^{3} \text { of blood, in mln }\end{array}$ & $\begin{array}{l}3.02^{* *} \\
\pm 0.26\end{array}$ & $\begin{array}{r}2.96 \\
\pm 0.11\end{array}$ & $\begin{array}{l}3.43 \\
\pm 0.28\end{array}$ & $\begin{array}{l}5.83^{* *} \\
\pm 0.14\end{array}$ & $\begin{array}{l}7.85^{*} \\
\pm 1.18\end{array}$ & $\begin{array}{r}8.70 \\
\pm 1.10\end{array}$ \\
\hline Hematocrit index & $\begin{array}{l}41.56^{* *} \\
\pm 1.69\end{array}$ & $\begin{array}{r}33.16 \\
\pm 1.89\end{array}$ & $\begin{array}{r}30.90 \\
\pm 1.84\end{array}$ & $\begin{array}{l}42.55^{* *} \\
\pm 2.30\end{array}$ & $\begin{array}{r}46.94 \\
\pm 7.19\end{array}$ & $\begin{array}{r}49.25 \\
\pm 6.91\end{array}$ \\
\hline $\begin{array}{l}\mathrm{Hb} \text { content in } \mathrm{g} \text { per } \\
100 \mathrm{ml} \text { of blood }\end{array}$ & $\begin{array}{l}13.01^{* *} \\
\pm 1.25\end{array}$ & $\begin{array}{r}10.13 \\
\pm 0.81\end{array}$ & $\begin{array}{r}8.17 \\
\pm 1.18\end{array}$ & $\begin{array}{l}11.68^{* *} \\
\pm 1.02\end{array}$ & $\begin{array}{c}14.51^{*} \\
\pm 1.93\end{array}$ & $\begin{array}{r}15.57 \\
\pm 0.60\end{array}$ \\
\hline $\begin{array}{l}\text { Mean erythrocyte volume } \\
\text { in } \mu^{3}\end{array}$ & $\begin{array}{l}138.12^{* *} \\
\pm 8.43\end{array}$ & $\begin{array}{l}112.33 \\
\pm 9.38\end{array}$ & $\begin{array}{r}90.47 \\
\pm 6.99\end{array}$ & $\begin{array}{l}73.81^{* *} \\
\pm 8.06\end{array}$ & $\begin{array}{r}60.15 \\
\pm 15.36\end{array}$ & $\begin{array}{r}56.86 \\
\pm 7.43\end{array}$ \\
\hline $\begin{array}{l}\text { Mean } \mathrm{Hb} \text { content in } \\
\text { erythrocyte in gamma-gamma }\end{array}$ & $\begin{array}{l}43.16^{* *} \\
\pm 2.34\end{array}$ & $\begin{array}{r}34.17 \\
\pm 1.58\end{array}$ & $\begin{array}{r}23.82 \\
\pm 0.63\end{array}$ & $\begin{array}{l}20.20^{* *} \\
\pm 2.21\end{array}$ & $\begin{array}{r}18.60 \\
\pm 2.48\end{array}$ & $\begin{array}{r}17.88 \\
\pm 1.19\end{array}$ \\
\hline $\begin{array}{l}\text { Mean } \mathrm{Hb} \text { concentration in } \\
\text { erythrocyte in } \%\end{array}$ & $\begin{array}{r}31.30 \\
\pm 1.64\end{array}$ & $\begin{array}{r}30.69 \\
\pm 4.10\end{array}$ & $\begin{array}{r}26.44 \\
\pm 1.66\end{array}$ & $\begin{array}{l}27.44^{* *} \\
\pm 1.32\end{array}$ & $\begin{array}{r}31.07 \\
\pm 2.80\end{array}$ & $\begin{array}{r}31.94 \\
\pm 4.30\end{array}$ \\
\hline $\begin{array}{l}\text { Number o leucocytes per } 1 \mathrm{~mm}^{3} \\
\text { of blood, in thousands }\end{array}$ & $\begin{array}{r}10.05 \\
\pm 2.75\end{array}$ & $\begin{array}{r}5.30 \\
\pm 0.96\end{array}$ & $\begin{array}{r}10.10 \\
\pm 5.89\end{array}$ & $\begin{aligned} & 7.40^{*} \\
\pm & 2.63\end{aligned}$ & $\begin{array}{r}10.50 \\
\pm 3.85\end{array}$ & $\begin{array}{r}10.11 \\
\pm 4.64\end{array}$ \\
\hline
\end{tabular}

** Differences statistically highly significant.

* Statistically significant differences, 
serum of skunk-ferret hybrids (Plate XIII: Fig. 1-5). Four protein fractions were found in the blood serum of newborn skunk-ferret hybrids: albumins, alfa globulins, beta globulins, gamma globulins. In older animals alfa and beta globulins divided into two fractions. Quantitative changes in the electrophoregram are shown in Table 2.

The behaviour of the gamma globulin fraction of blood serum proteins during the period of the hybrids' growth deserves special mention. The high level of this fraction in the blood of day-old cubs may be due to acquiring antibodies from the mother during embryonic life and to the newborn cubs ingesting colostrum rich in gamma globulin. The increase of gamma globulin in the blood serum of newborn animals after ingesting colostrum has been observed in previous studies (B i eguszewski, 1966) and Nagórski (1960; 1970).

Table 2

Blood serum proteins in skunk $\times$ ferret hybrids of different age.

\begin{tabular}{lcccc}
\hline \multirow{2}{*}{$\begin{array}{l}\text { Age of } \\
\text { animals }\end{array}$} & Albumins in $\%$ & \multicolumn{3}{c}{ Globulins in \% } \\
\cline { 3 - 5 } & & alpha & beta & gamma \\
\hline one day & 42.76 & $21.58^{* *}$ & $10.30^{* *}$ & 25.36 \\
& \pm 3.24 & \pm 3.49 & \pm 2.43 & \pm 3.10 \\
7 days & 46.95 & 18.64 & 13.68 & 20.73 \\
& \pm 4.53 & \pm 3.49 & \pm 1.96 & \pm 3.11 \\
30 days & 41.68 & 26.52 & 15.60 & 16.20 \\
& \pm 2.48 & \pm 4.54 & \pm 3.76 & \pm 2.57 \\
4.5 months & $39.46^{* *}$ & $18.72^{* *}$ & $25.85^{* *}$ & $15.98^{* *}$ \\
& \pm 5.49 & \pm 3.71 & \pm 3.52 & \pm 2.82 \\
7.5 months & 44.25 & 10.59 & 19.48 & 25.68 \\
& \pm 3.91 & \pm 1.96 & \pm 2.17 & \pm 3.22 \\
\hline
\end{tabular}

** Differences statististically highly significant.

The marked decrease in percentage of gamma globulin content in individuals 30 days old was due to the fact that the animals' own fully effective resistance mechanisms had not yet formed and also to the disappearance of certain of these antibodies which suckling cubs obtained together with colostrum during the first few days of life. It is known that gamma globulins are proteins with a semi-persistence period of several days (Bogdanikowa \& M urawski, 1968).

It must be assumed that the highest level of gamma globulin in skunk-ferret hybrids 7.5 months old was connected with the complete formation of the resistance mechanism or with the action of additional antigen factors.

The relatively high contents of alfa globulin in the blood serum of 
16. Tomaszewski L., 1970: Mikrometody biochemiczne w labolatorium klinicznym. Państw. Zakł. Wyd. Lek.: 1-308. Warszawa.

Accepted, August 24, 1977.

Henryk BIEGUSZEWSKI i Roman SZYMECZKO

SKŁADNIKI MORFOLOGICZNE I BIAŁKA SUROWICY KRWI U TCHORZOFRETEK W OKRESIE POSTNATALNYM

\section{Streszczenie}

Przeprowadzono badania krwi na 75 tchórzofretkach różnego wieku. Oznaczono liczbę krwinek czerwonych i białych w $1 \mathrm{~mm}^{3}$ krwi, hematokryt, zawartość hemoglobiny i elektroferetyczny obraz białek surowicy krwi. Stwierdzono niedokrwistość fizjologiczną, która objawiła się niskim poziomem krwinek czerwonych, hematokrytu i hemoglobiny krwi tchórzofretek. W elektroretycznym obrazie surowicy krwi wykazano największą zmienność w zakresie globulin. Należy przypuszczać, że wysoki poziom gamma globulin $\mathrm{u}$ tchórzofretek 1 dniowych spowodowanych był wchłonięciem dużej ilości przeciwciał z siary. 


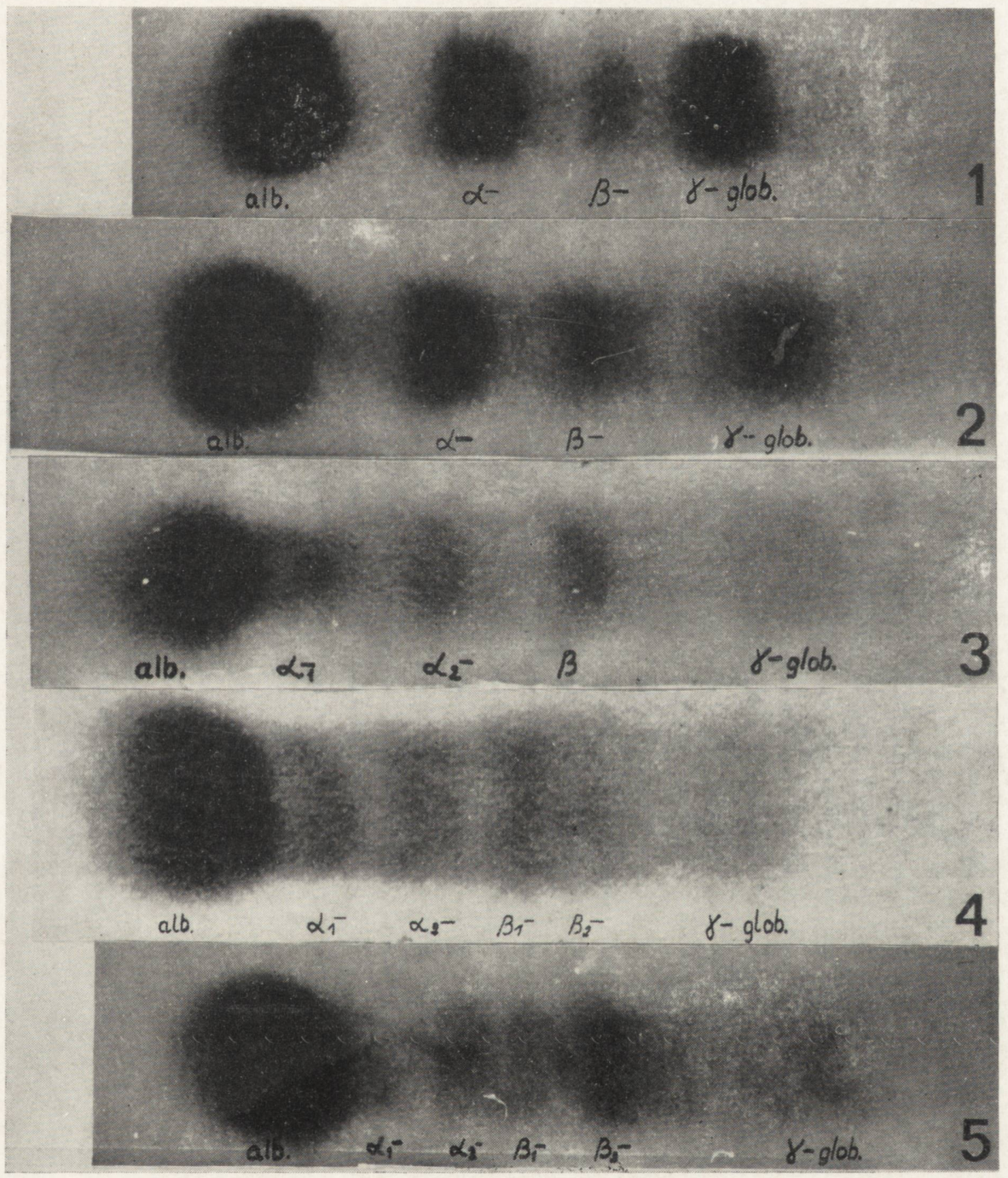

